ROZDZIAŁ 2

\title{
Definicje pojęć podstawowych
}

\subsection{Przegląd proponowanych definicji}

Pojęcie rewitalizacji odnosi się do działań skierowanych na istniejące przestrzenie zurbanizowane, w odróżnieniu od pojęć definiujących aktywności skierowane na planowanie i realizowanie nowych zespołów zabudowy na terenach dotychczas nie zabudowanych. Pojawienie się tego określenia zostało poprzedzone przez wiele pojęć o zbliżonym znaczeniu, jednak odrębnych pod względem znaczeniowym. Szczegółową analizą tych pojęć, takich jak: odnowa, przebudowa, restrukturyzacja, regeneracja, rehabilitacja, rewaloryzacja, a także recykling (powtórne wprowadzenie do użytku) zajmuje się w swojej pracy dotyczącej rewitalizacji terenów poprzemysłowych w miastach Sylwia Kaczmarek ${ }^{1}$.

Pojęcie rewitalizacji jest często nadużywane, szczególnie w kontekście określania tym mianem działań tylko i wyłącznie budowlanych - remontowych lub modernizacyjnych. Należy pamiętać, iż w ramach procesu rewitalizacji konieczne jest uwzględnienie aspektu społeczno-gospodarczego, a działania przestrzenne, w tym budowlane, tworzyć mają materialne warunki do odnowy i rozwoju.

Dla działań o węższym zakresie problemowym niż rewitalizacja stosowane są przede wszystkim następujące pojęcia:

- remont - w przypadku przywrócenia takiego stanu budynku, jaki istniał na początku cyklu eksploatacji;

- modernizacja - w odniesieniu do remontu wraz z wprowadzeniem nowych, lepszych, sprawniejszych lub nawet dodatkowych elementów wyposażenia, podnoszących standard użytkowy budynku;

- rewaloryzacja - w sytuacji dążenia do przywrócenia utraconych wartości architektonicznych i użytkowych poprzez remont i modernizację obiektów o szczególnej wartości zabytkowej.

Rewitalizacja - jako pojęcie o szerszym od wymienionych powyżej znaczeniu - obejmuje wszystkie powyższe zakresy, odnosząc się do kompleksowych procesów odnowy podejmowanych $\mathrm{w}$ obszarach miejskich i na terenach

${ }^{1}$ S. Kaczmarek, Rewitalizacja terenów poprzemysłowych. Nowy wymiar w rozwoju miast, Łódź 2001. 
poprzemysłowych, wiążąc działania techniczno-budowlane ze zmierzającymi do ożywienia społecznego i gospodarczego ${ }^{2}$.

Termin rewitalizacja pojawia się $\mathrm{w}$ wielu dziedzinach zajmujących się przekształceniami struktur miejskich: urbanistyce, socjologii, geografii czy naukach zajmujących się zarządzaniem miastem i regionem. Stąd też w definicjach tego pojęcia, w poszczególnych publikacjach, możemy zaobserwować odpowiednio silniejsze akcentowanie aspektów przestrzennych, społecznych lub ekonomicznych, w zależności od postrzegania przez autorów ważności poszczególnych aspektów rewitalizacji.

Zbigniew Zuziak koncentruje się na zagadnieniach związanych z procesem pobudzania przemian przestrzeni miejskiej w celu odwrócenia zjawisk degradacji i podniesienia konkurencyjności miasta. Podkreśla on rolę skoordynowanych działań sektora publicznego i prywatnego w ramach rewitalizacji obszarów śródmiejskich, prowadzących do osiągnięcia pozytywnych zmian strukturalnych w zakresie wzmacniania aktywności i atrakcyjności przestrzeni miejskiej ${ }^{3}$.

Aspekty społeczne i ekonomiczne są głównymi wątkami w definicji pojęcia rewitalizacji formułowanej przez Tadeusza Markowskiego. Określa on degradację terenów miejskich jako ich marginalizację, czyli wyłączenie z pozytywnego funkcjonowania pod względem społecznym i gospodarczym. Zwraca on uwage na generowanie wartości ziemi jako podstawę koncepcji rewitalizacji obszarów miejskich:

Podejmując się polityki rewitalizacyjnej obszarów problemowych w miastach, należy sobie zdawać sprawę ze związków, jakie tutaj zachodzą pomiędzy generowaniem wartości ziemi, jej ceną, rentą, efektami zewnętrznymi a systemem podatków od wartości nieruchomości. [...] Pojawienie się korzyści zewnętrznych na przekształcanym obszarze jest możliwe tylko przy dużej skali tych przekształceń. Przekształcenie tkanki miejskiej jest bowiem czasochłonne, a korzyści ujawniają się tylko $\mathrm{w}$ długim okresie. Zatem indywidualne, nie skoordynowane w czasie inwestycje nie są w stanie przywrócić możliwości generowania wysokiej renty na danym terenie ${ }^{4}$.

Markowski podkreśla konieczność koncentracji środków finansowych i działań rewitalizacji na niewielkim obszarze, umożliwiającym osiagnięcie tzw. „efektu kuli śniegowej” (spill-over), czyli pozytywnego oddziaływania efektów procesu rewitalizacji na obszary przylegające oraz na niezbędny udział i kontrolę ze strony władzy publicznej.

$\mathrm{W}$ projekcie ustawy o programach rewitalizacji ${ }^{5}$ podkreśla się społeczny aspekt procesu rewitalizacji: autorzy projektu definiują rewitalizację jako

${ }^{2}$ E. Zawadzki, Analiza funkcjonujacych programów modernizacyjnych miejskich zasobów mieszkaniowych i użyteczności publicznej, 1999.

${ }^{3}$ Z. Zuziak, Strategie rewitalizacji przestrzeni śródmiejskiej, Kraków 1998.

${ }^{4}$ T. Markowski, Zarzq̨dzanie rozwojem miast, Warszawa 1999, s. 128.

${ }^{5}$ Projekt ustawy o programach rewitalizacji, 2003. 
działania adresowane do obszarów kryzysowych, zdegradowanych, zmierzające do rozwoju społeczności lokalnej:

Celem rewitalizacji jest doprowadzenie do rozwoju obszarów kryzysowych poprzez realizację zarządzanych przez sektor publiczny programów i projektów. Podmiotami odpowiedzialnymi za ten proces i w nim bezpośrednio uczestniczącymi są: gmina, pełnomocnicy do spraw rewitalizacji, właściciele nieruchomości, Towarzystwa Odnowy oraz mieszkańcy obszaru dotkniętego kryzysem. W myśl takiej definicji rewitalizacja dokonuje się przede wszystkim w kontekście społecznym. Jej celem jest rozwój społeczny, któremu służyć winny działania rewitalizacyjne, $\mathrm{w}$ tym te mające na celu modernizację zabudowy. Takie rozumienie rewitalizacji wywodzi się zarówno z założeń trwałego i zrównoważonego rozwoju, jak i integruje założenia i praktykę nowych europejskich programów „rewitalizacji socjalnej ${ }^{6}$.

Krzysztof Skalski określa proces rewitalizacji jako kompleksowy program dzialań technicznych - remontów zabudowy, modernizacji przestrzeni publicznych oraz rewaloryzacji obiektów dziedzictwa kulturowego na wybranym obszarze, w powiązaniu $z$ rozwojem gospodarczym i dzialaniami na rzecz rozwiązywania problemów spolecznych ${ }^{7}$.

Jerzy Parysek, pisząc o rewitalizacji miejskiej, podkreśla rolę tego procesu dla przemian zachodzących w fizjonomii miast, charakteryzując go jako odnowę i regenerację zdegradowanych elementów struktury miejskiej w celu przywrócenia utraconych lub nadania nowych funkcji:

Termin rewitalizacja wydaje się być szczególnie pojemnym, a ponadto oddaje istotę procesu, którego dotyczy, zwłaszcza $\mathrm{w}$ odniesieniu do miast. W rewitalizacji w gruncie rzeczy chodzi bowiem o ponowne ożywienie zdegradowanych części miasta, z czym wiąże się zarówno renowacja czy odnowa substancji materialnej, jak i regeneracja, czyli odtworzenie i odświeżenie uszkodzonych elementów struktury miejskiej. Wydaje się, że termin rewitalizacja posiada swoje uzasadnienie w Nowej Karcie Ateńskiej z 1998 roku, w której akcentowana jest potrzeba odnawiania zabudowy miejskiej w nawiązaniu do struktury miasta i jego formy urbanistycznej ${ }^{8}$.

W praktyce działań rewitalizacji w Wielkiej Brytanii przyjmuje się zwięzła, ale bardzo trafną i obrazową definicję rewitalizacji, określając tym mianem „Proces odwrócenia ekonomicznego, społecznego i fizycznego rozkładu miast, w sytuacji, gdy rozkład ten osiagnął stadium, w którym same siły rynkowe już nie wystarczają" . Definicja ta wydaje się szczególnie ważna ze względu na podkreślenie charakterystycznej cechy stanu wyjściowego obszaru kwalifikującego się do podjęcia rewitalizacji, a mianowicie utraty zdolności samoregenera-

${ }^{6}$ Podręcznik rewitalizacji. Zasady, procedury i metody działania wspótczesnych procesów rewitalizacji, Warszawa 2003, s. 18.

${ }^{7}$ K. Skalski, Rewitalizacja obszarów starej zabudowy w miastach, mps., s. 1.

${ }^{8}$ J. J. Parysek, Miasta polskie na przełomie XX i XXI wieku. Rozwój i przeksztatcenia strukturalne, Poznań 2005.

${ }^{9}$ European Sustainable Cities Report, Expert Group on the Urban Environment, European Commission, Directorate General XI, Brussels, March 1996. 
cji. W takim właśnie wypadku rewitalizacja jest niezbędnym instrumentem przywracania obszaru do właściwego funkcjonowania w organizmie miejskim.

W Zintegrowanym Programie Rewitalizacji obszarów centralnych Łodzi Prorevita $^{10}$, zespół naukowo-badawczy przyjął następującą definicję rewitalizacji:

- Rewitalizacja jest długofalowym i wielopłaszczyznowym procesem, dotyczącym problemów społecznych, gospodarczych i przestrzennych występujących na danym terenie.

- Programami rewitalizacji obejmowane są tereny, które w sposób dramatyczny utraciły możliwość funkcjonowania na dotychczasowych zasadach - na skutek przemian gospodarczych prowadzących do likwidacji istniejących uprzednio na tych terenach miejsc pracy oraz negatywnych zmian prowadzacych do degradacji przestrzeni miejskiej.

- Tereny takie objęte są również nasileniem bezrobocia i patologii społecznych.

- Rewitalizacja tych obszarów miasta ma na celu wprowadzenie nowej funkcji, tworzącej podstawy ekonomicznego ożywienia i stabilnego funkcjonowania zagrożonych terenów, przy jednoczesnym rozwiązywaniu problemów społecznych, m.in. poprzez proces angażowania członków lokalnych społeczności $\mathrm{w}$ proces rewitalizacji, prowadzenie działań rehabilitacji społecznej oraz tworzenie nowych miejsc pracy.

- Celem rewitalizacji jest podniesienie jakości życia na danym obszarze kryzysowym oraz zmiana jego statusu w całym organizmie miejskim ${ }^{11}$.

Przytoczona wyżej definicja akcentuje przede wszystkim kwestię długofalowości i konieczności cyklicznej aktualizacji programów rewitalizacji, a także integracji działań w celu rozwiązywania problemów przestrzennych, społecznych i gospodarczych.

Dla potrzeb niniejszego opracowania przyjęto następującą definicję rewitalizacji: Rewitalizacja jest procesem długofalowym i wielopłaszczyznowym procesem integrującym dzialania naprawcze $w$ sferze przestrzennej, społecznej i gospodarczej, adresowanym do zdegradowanych terenów miejskich, które utracily zdolność samoregeneracji, prowadzonym $\mathbf{w}$ celu ponownego włączenia tych obszarów w funkcjonowanie organizmu miejskiego.

Zespół naukowy Instytutu Rozwoju Miast w ramach prac badawczych związanych z realizacją grantu zamawianego poświęconego rewitalizacji miast polskich $^{12}$ wyróżnił następujące typy procesu rewitalizacji:

${ }^{10}$ Zintegrowany Program Rewitalizacji obszarów centralnych Łodzi Prorevita został zaprezentowany w książce A. Wojnarowskiej Rewitalizacja zdegradowanych obszarów miejskich. Przykłady praktyczne, Łódź 2011.

${ }^{11}$ Zintegrowany Program Rewitalizacji obszarów centralnych Łodzi Prorevita, Etap I, Łódź 2004.

${ }^{12}$ Projekt badawczy-zamawiany pt. Rewitalizacja miast polskich jako sposób zachowania dziedzictwa materialnego i duchowego oraz czynnik zrównoważonego rozwoju, realizowany przez IRM od czerwca 2007 do czerwca $2010 \mathrm{r}$. 
- rewitalizacja zdegradowanych śródmieść i wielofunkcyjnych przedwojennych obszarów zabudowy miejskiej,

- rewitalizacja obszarów poprzemysłowych, pokolejowych i powojskowych,

- rewitalizacja blokowisk, w tym szczególnie blokowisk wzniesionych w technologii wielkopłytowej

- rewitalizacja krajobrazu miast ze szczególnym uwzględnieniem sylwety miasta i systemu przestrzeni publicznych, w tym zieleni miejskiej ${ }^{13}$.

W niniejszej pracy przyjęto natomiast, iż w zależności od dominującej funkcji obszaru podlegającego przemianom $\mathrm{w}$ ramach procesu rewitalizacji, charakterystycznych objawów degradacji i podejmowanych działań, wyróżnić możemy trzy podstawowe typy procesu rewitalizacji:

- rewitalizację zdegradowanych obszarów o funkcji mieszanej: śródmiejskich i staromiejskich

- rewitalizację wielorodzinnych osiedli mieszkaniowych - tzw. humanizację blokowisk

- rewitalizację opuszczonych terenów monofunkcyjnych: poprzemysłowych, poportowych, postoczniowych, pokolejowych, pomilitarnych.

Trzeba w tym miejscu podkreślić, że typologia ta ma charakter „nieostry”, wynikający z faktu, iż często obiekty i obszary poprzemysłowe zlokalizowane są $\mathrm{w}$ strefach centralnych miast i na terenie XIX-wiecznych śródmieść. Taka sytuacja powoduje konieczność rozpatrywania zagadnień dotyczących rewitalizacji tych obszarów i obiektów łącznie z kwestią rewitalizacji otaczających obszarów śródmiejskich.

$\mathrm{Z}$ kolei zagadnienia związane $\mathrm{z}$ rewitalizacją obszarów poportowych, doków i terenów postoczniowych w bliski sposób powiązane są z problematyką rewitalizacji staromiejskich centrów miast - ze względu na specyficzną strukturę przestrzenną miast portowych, które w swoim historycznym rozwoju przestrzennym wykształciły centrum w sąsiedztwie nabrzeży wodnych i portów, tereny te stanowią potencjalny obszar rozwoju funkcji ogólnomiejskich i rozbudowy strefy centralnej miasta.

\subsection{Cele rewitalizacji}

Zgodnie $\mathrm{z}$ definicją przyjętą $\mathrm{w}$ poprzednim rozdziale, rewitalizacja jest procesem długofalowym i wielopłaszczyznowym, mającym na celu rozwiązywanie problemów społecznych, gospodarczych i przestrzennych występujących na danym terenie. Programami rewitalizacji obejmowane są tereny, które utraciły

${ }^{13}$ W. Jarczewski, Skala degradacji miast w Polsce, [w:] W. Jarczewski (red.), Przestrzenne aspekty rewitalizacji - śródmieścia, blokowiska, tereny poprzemysłowe, pokolejowe i powojskowe, Seria: Rewitalizacja Miast Polskich, t. 4, Kraków 2009. 
możliwość funkcjonowania na dotychczasowych zasadach - na skutek negatywnych zmian prowadzących do degradacji przestrzeni miejskiej oraz przemian gospodarczych prowadzących do likwidacji miejsc pracy. Tereny takie objęte są zazwyczaj nasileniem zjawisk bezrobocia i patologii społecznych. Rewitalizacja tych obszarów miasta ma na celu rozbudowę funkcji istniejących lub wprowadzenie nowych, tworzących podstawy ekonomicznego ożywienia i stabilnego funkcjonowania zagrożonych terenów, przy jednoczesnym rozwiązywaniu problemów społecznych, m.in. poprzez angażowanie członków lokalnych społeczności w proces rewitalizacji, prowadzenie działań rehabilitacji społecznej oraz tworzenie nowych, stałych miejsc pracy. Celem rewitalizacji jest podniesienie jakości życia na danym obszarze kryzysowym oraz poprawa jego statusu $\mathrm{w}$ całym organizmie miejskim.

Istotą procesu rewitalizacji nie jest wprowadzanie krótkotrwałych zmian, lecz uzyskanie trwałej poprawy warunków panujących na danym obszarze, co wymaga wieloletnich, starannie zaplanowanych i wdrażanych prac. W związku $\mathrm{z}$ tym proces rewitalizacji musi prowadzić do uzyskania stanu samoregeneracji obszarów, aby uniknąć przemiennego następowania po sobie okresów ożywienia i degradacji. Oznacza to, że po zakończeniu procesu rewitalizacji i wycofaniu wspomagania zewnętrznego za pomocą różnorakich środków i działań, obszar zrewitalizowany będzie $\mathrm{w}$ stanie o własnych siłach pozytywnie funkcjonować w całości struktury miejskiej.

Możemy określić uszczegółowione cele rewitalizacji dla poszczególnych typów procesu rewitalizacji. Rewitalizacja miejskich obszarów zdegradowanych ma na celu ich ożywienie gospodarcze i społeczne, zwiększenie potencjału turystycznego i kulturalnego oraz zapobieżenie dalszemu zjawisku suburbanizacji poprzez tworzenie korzystnych warunków dla zamieszkania, pracy, rekreacji i inwestowania w śródmieściu, także poprzez podniesienie poziomu bezpieczeństwa i jakości środowiska.

Podstawowym zadaniem rewitalizacji obszarów i obiektów poprzemysłowych jest $\mathrm{z}$ kolei zagospodarowanie nieużytkowanych obiektów i terenów poprzez ich adaptację na nowe funkcje - przede wszystkim handlowe, usługowe, kulturalne, edukacyjne, społeczne, zdrowotne, rekreacyjne i turystyczne, a także mieszkaniowe ${ }^{14}$.

Działania określane mianem humanizacji blokowisk mają na celu doprowadzenie tkanki budowlanej oraz otoczenia zabudowy do współczesnych standardów technologicznych i estetycznych oraz uzupełnienie braków w wyposażeniu w urządzenia infrastruktury komunikacyjnej, usługowej, społecznej, kulturalnej i rekreacyjnej. Dzięki realizacji projektów rewitalizacji w tym zakresie, obszary

${ }^{14}$ Uzupetnienie Zintegrowanego Programu Rozwoju Regionalnego 2004-2006, DzU 2006, nr 102, poz. 706, (tekst jednolity uwzględniający zmiany przyjęte przez Komitet Monitorujący ZPORR w dniu 17 stycznia 2007). 
wielorodzinnej zabudowy blokowej mają szansę stać się atrakcyjnym środowiskiem mieszkaniowym, bezpiecznym i o wysokich walorach życia społecznego.

Zadania wykonywane $\mathrm{w}$ ramach programów rewitalizacji obejmują przede wszystkim poprawę stanu technicznego zabudowy i infrastruktury, poprawę stanu środowiska miejskiego, właściwe wykorzystanie zasobów dziedzictwa kulturowego - często $\mathrm{w}$ powiązaniu z adaptacją dla nowych funkcji, rozwiązywanie problemów społecznych oraz zwiększenie potencjału gospodarczego obszaru. Realizacja programów rewitalizacji powinna wpływać znacząco na zmianę jakościową relacji społecznych i ekonomicznych, powodując ugruntowanie miejskiej kultury życia i interakcji społecznych oraz zwiększenie poczucia identyfikacji społeczności lokalnych z miejscem zamieszkania, prowadząc do aktywnych zachowań wspólnotowych w przestrzeni „małych ojczyzn”. Czynnikiem sprzyjającym tym zjawiskom jest wzrost jakości współczesnych przestrzeni miejskich, ich estetyki, funkcjonalności, bezpieczeństwa i swoistej otwartości na uspołecznienie życia w miastach ${ }^{15}$.

\subsection{Przestrzenne, społeczne i ekonomiczne aspekty rewitalizacji}

Przytoczone w rozdz. 2.1. definicje rewitalizacji ukazują trzy różne, a zarazem nierozłączne aspekty problemu rewitalizacji: przestrzenny, społeczny i gospodarczy. Aspekt nazwany tutaj przestrzennym obejmuje problemy związane z fizycznym kształtem środowiska miejskiego: kwestie architektoniczno-urbanistyczne i budowlane, ekologiczne, infrastruktury technicznej i dziedzictwa kulturowego.

Problematyka spoleczna $w$ programach rewitalizacji to przede wszystkim zagadnienia związane $\mathrm{z}$ występowaniem patologii społecznych, zjawiskiem wykluczenia społecznego, zmianami demograficznymi, pauperyzacją niskim stopniem wykształcenia. To także kwestie dotyczące możliwości równego udziału w życiu społecznym i gospodarczym osób niepełnosprawnych, starszych i kobiet.

Aspekt ekonomiczny związany jest z gospodarczą kondycją rewitalizowanego obszaru i koniecznością doprowadzenia do ożywienia gospodarczego, a co za tym idzie - powstania nowych stałych miejsc pracy, poprzez wspieranie lokalnych przedsiębiorców, tworzenie zachęt dla inwestorów zewnętrznych oraz przyciaganie nowych mieszkańców i użytkowników.

Wszystkie te aspekty powinny być traktowane w sposób zintegrowany: projekty rewitalizacji należy konstruować w sposób przyczyniający się do powstania efektu synergii - korzyści płynące z realizacji tak skonstruowanych działań

${ }^{15}$ A. Muzioł-Wencławowicz, Rewitalizacja dzielnic śródmiejskich, [w:] W. Jarczewski (red.), Przestrzenne aspekty... 
będą wówczas przekraczać sumę korzyści, które powstałyby w wyniku wykonania zadań odnoszących się do poszczególnych problemów, np.:

- remont i adaptacja do nowych funkcji obiektu poprzemysłowego, z uwzględnieniem wymogów ekologicznych oraz celów lokalnej przedsiębiorczości, promującej zatrudnienie osób bezrobotnych lub znajdujących się $\mathrm{w}$ sytuacji wykluczenia społecznego;

- rewaloryzacja obiektu historycznego z przystosowaniem do celów społecznych lub kulturalnych, $\mathrm{z}$ wprowadzeniem funkcji edukacyjno-opiekuńczo-społecznych, z zatrudnieniem do prowadzenia zajęć osób z odpowiednim wykształceniem lub przeszkolonych w ramach kursów prowadzonych w obszarze rewitalizacji itd.

\subsection{Badanie zjawisk kryzysowych. Kryteria identyfikacji obszarów kryzysowych}

Sprawą kluczową dla przystapienia do opracowania programu rewitalizacji jest identyfikacja obszaru objętego zjawiskami kryzysowymi. Wstępne określenie obszarów kryzysowych bazuje na danych i informacjach posiadanych przez gminę oraz bezpośrednich obserwacjach, a także wnioskach zgłaszanych przez mieszkańców i właścicieli. Dane te umożliwiają wyznaczenie obszarów „wymagających przekształceń, rehabilitacji lub rekultywacji” w studium uwarunkowań i kierunków zagospodarowania przestrzennego ${ }^{16}$.

Diagnozowane zjawiska kryzysowe występujące na tych obszarach dotyczą sfery problemów przestrzennych, społecznych i ekonomicznych. W ramach badania tych zjawisk należy $\mathrm{w}$ maksymalnym stopniu wykorzystać dostępne dane. Bezcelowe jest tworzenie zbyt szerokich analiz i szczegółowych badań statystycznych, które zwiększają w istotny sposób wydatki na ten etap opracowania programu rewitalizacji, nie przynosząc proporcjonalnych do nakładów efektów. Duża część informacji szczegółowych jest często uzyskiwana przez operatora rewitalizacji w ramach konsultacji i współpracy z lokalną społecznością, służąc do konstrukcji programu i późniejszych jego aktualizacji.

W ramach badania zjawisk kryzysowych sfery przestrzennej wyróżnić możemy następujące podstawowe zjawiska, będące źródłem problemów i deficytów:

- struktura własności,

- infrastruktura podziemna,

- stan techniczny zabudowy,

- jakość ulic, placów i zieleni publicznej,

- estetyka przestrzeni publicznej,

${ }^{16}$ Art. 10 pkt. 2, Ustawa o planowaniu i zagospodarowaniu przestrzennym z dnia 27 marca 2003 r. (DzU 2003, nr 80). 
- ochrona zabytków,

- komunikacja (ruch i parkowanie),

- rozkład i jakość funkcji handlowych i usługowych,

- mieszkalnictwo - tu w szczególności: wiek budynków, liczba mieszkań, wielkość mieszkań $\mathrm{w} \mathrm{m}^{2}$, liczba pomieszczeń, stan wyposażenia mieszkań w kuchnie, sanitariaty, łazienki, piwnice, liczba gospodarstw domowych i mieszkańców przypadających na 1 mieszkanie i na $1 \mathrm{~m}^{2}$, otoczenie budynków, wnętrza kwartałów,

- infrastruktura socjalna,

- stan środowiska.

W zakresie badania zjawisk kryzysowych sfery ekonomicznej i społecznej należy uwzględnić następujące obszary problemowe:

- gospodarka i rynek pracy,

- położenie socjalne,

- poziom i struktura wykształcenia,

- szanse zawodowe i społeczne,

- stopień aktywności i gotowości społeczności miejscowej do działań partycypacyjnych,

- stopień identyfikacji społeczności lokalnej z obszarem kryzysowym.

W ramach badań należy określić, które zjawiska kryzysowe wywoływane są przez czynniki lokalne, a które zależne są od czynników zewnętrznych ${ }^{17}$.

Należy w tym miejscu zwrócić uwagę na fakt, że w Polsce uzyskanie danych statystycznych umożliwiających określenie zjawisk kryzysowych w danym obszarze napotyka duże trudności. Dla delimitacji obszarów o największej kumulacji zjawisk kryzysowych należałoby dokonać analizy pod kątem występowania tych zjawisk $\mathrm{w}$ skali całego miasta. Jednakże miasta polskie nie posiadają tego typu opracowań, a dane statystyczne gromadzone przez urzędy statystyczne agregowane są dla innych obszarów niż te, które należałoby badać pod kątem występowania zjawisk kryzysowych ${ }^{18}$. Często dane te (np. stopa bezrobocia, liczba osób korzystających z pomocy społecznej, poziom zanieczyszczenia powietrza atmosferycznego) podawane są dla całego miasta lub jednostek podziału administracyjnego, lub obrębów statystycznych, który to podział oczywiście nie pokrywa się z „mapa” występowania obszarów kryzysowych $^{19}$. Dla potrzeb zintegrowanego zarządzania rozwojem miasta należałoby dane opisujące stan przestrzenny, gospodarczy i społeczny poszczególnych

${ }^{17}$ Podręcznik rewitalizacji...

${ }^{18}$ Jedynie w rzadkich przypadkach - jak opracowanie Zintegrowanego Programu Rewitalizacji obszarów centralnych Łodzi Prorevita - wykonywane są kompleksowe i szczegółowe badania poszczególnych zjawisk kryzysowych w obszarach zdegradowanych. Podstawową barierą wykonywania tego rodzaju analiz jest ich koszt oraz czas trwania prac.

${ }^{19}$ BIG Staedtebau, Konkurs na LPR Krakowa, 2006. 
rejonów miasta zbierać dla inaczej wydzielonych jednostek - np. dla jednostek sąsiedzkich $^{20}$.

Dla delimitacji obszaru kryzysowego stosowany jest zestaw kryteriów wskazujących na poziom poszczególnych zjawisk kryzysowych w odniesieniu do średniej krajowej. Przyjmuje się, że obszar uznany może być za kryzysowy, jeśli występują na nim jednocześnie co najmniej trzy spośród niżej wymienionych kryteriów, przy wielkości wskaźników przekraczających średnie wartości dla miasta:

1) wysoki poziom bezrobocia mieszkańców,

2) wysoki poziom ubóstwa oraz trudne warunki mieszkaniowe,

3) wysoki poziom przestępczości,

4) niski poziom wykształcenia mieszkańców,

5) niski poziom przedsiębiorczości mieszkańców,

6) wysoki poziom degradacji technicznej infrastruktury i budynków,

7) wysoki poziom zanieczyszczenia środowiska naturalnego.

Przedstawiona powyżej metoda delimitacji obszaru kryzysowego oparta została na kryteriach wypracowanych w ramach inicjatywy UE Urban II.

\subsection{Uczestnicy procesu rewitalizacji}

Możemy wskazać dwie zasadnicze grupy uczestników procesu rewitalizacji: $z$ jednej strony są to instytucje i podmioty zajmujące się organizacją i wdrażaniem tego procesu, z drugiej strony są adresaci tych działań. Organizatorem działań są władze samorządowe oraz współdziałające $\mathrm{z}$ nimi jednostki wykonawcze. Adresatami działań są z jednej strony osoby fizyczne i prawne już związane z obszarem rewitalizacji: przede wszystkim mieszkańcy, właściciele nieruchomości, najemcy, przedsiębiorcy, organizacje społeczne, gospodarcze, związki wyznaniowe, instytucje publiczne oraz potencjalni nowi użytkownicy i inwestorzy zaliczający się do każdej z wcześniej wymienionych grup. Uczestnicy programu rewitalizacji nazywani są często „aktorami” procesu rewitalizacji.

\subsection{Zarządzanie procesem rewitalizacji. Operator rewitalizacji}

W celu efektywnej realizacji programu rewitalizacji konieczne jest sprawne i nie zagrożone fluktuacjami wynikającymi z kadencyjności władz lokalnych wdrażanie przyjętych zadań. Można wyróżnić cztery podstawowe modele wdrażania procesu rewitalizacji:

${ }^{20}$ Pisze o tym S. Kozłowski w rozdz. Doświadczenia rewitalizacji w miastach Wielkiej Brytanii, Francji i Niemiec. 
1. Gmina wykonuje całość przedsięwzięcia samodzielnie, przy zaangażowaniu jedynie swoich specjalistów, za pomocą utworzonej w tym celu jednostki w ramach własnego urzędu.

2. Gmina tworzy własną spółkę, delegując do niej zatrudnionych w strukturach administracyjnych specjalistów i przekazuje jej do realizacji całość zadań związanych z procesem rewitalizacji.

3. Gmina tworzy spółkę publiczno-prywatną z partnerem zewnętrznym - operatorem rewitalizacji i przekazuje mu do samodzielnej realizacji wszystkie zadania związane z procesem rewitalizacji.

4. Gmina powierza wyspecjalizowanej firmie zewnętrznej spoza Urzędu samodzielną realizację wszystkich zadań rewitalizacyjnych ${ }^{21}$.

W zasadzie wszystkie wymienione modele zapewniają sprawną organizację i realizację procesu rewitalizacji. Koordynacja działań i wdrażania zadań rewitalizacji w każdym modelu wymaga powołania instytucji pełnomocnika ds. rewitalizacji w ramach Urzędu Miasta, będącego łącznikiem pomiędzy jednostką wykonującą zadania a władzami samorządowymi.

W praktyce realizacji procesów rewitalizacji w krajach europejskich prowadzących rewitalizację od kilkudziesięciu lat sprawdziły się przede wszystkim warianty 3 i 4, w których gmina powierza prowadzenie programu rewitalizacji wyspecjalizowanej i mającej długoletnie doświadczenie firmie operatorskiej. Mankamentem rozwiązań 1 i 2, w których gmina wykonuje te zadania samodzielnie, jest najczęściej brak odpowiednio przygotowanej kadry oraz doświadczeń w tym zakresie.

Istotnym czynnikiem wskazującym na korzyści zastosowania wariantu 3 i 4 jest również fakt możliwości uzyskania dofinansowania $\mathrm{z}$ funduszy środków strukturalnych Unii Europejskiej, ponieważ działalność operatorów z wolnego rynku stanowi koszt kwalifikowany i może być finansowana ze środków pomocowych.

Aby zapewnić właściwą, zgodną $\mathrm{z}$ interesem publicznym realizację programu rewitalizacji, zewnętrzny menadżer - firma operatorska ds. rewitalizacji musi podlegać zobowiązaniom w tym samym stopniu, co gmina. Przy realizacji działan firma operatorska ds. rewitalizacji związana jest poleceniami i decyzjami władz samorządowych. W ten sposób nie tylko podlega ona kontroli publicznej, ale może wdrażać wyłącznie zamierzenia gminy. Wszystkie zadania władzy publicznej, jak również decyzje dotyczące planowania urbanistycznego, pozostają wyłącznym zadaniem gminy - chociaż oczywiście operator ds. rewitalizacji również bierze $\mathrm{w}$ nich udział lub przygotowuje procesy decyzyjne ${ }^{22}$.

${ }^{21}$ BIG Stadedtebau GmbH: G. Adamczyk-Arns, A. Wojnarowska, E. Feresztyn, F. Hultsch,

F. Hultsch, Miejski Program Rewitalizacji dla Miasta Krakowa, październik 2008, s. 27.

${ }^{22}$ BIG Staedtebau, Praca konkursowa na LPR Krakowa, październik 2006. 
Głównymi polami działalności operatora rewitalizacji są: pozyskiwanie, zarządzanie, wdrażanie i rozliczanie środków wspierających oraz przeprowadzenie konkretnych projektów rewitalizacji.

Oprócz stałych usług doradczych gmina może zlecić operatorowi następujące zadania:

- przeprowadzenie badań wstępnych rewitalizacji,

- przygotowanie prawnego określenia granic obszaru rewitalizacji,

- współpraca przy projektach urbanistycznych,

- prezentacja zamierzonego procesu rewitalizacji,

- opracowanie i prowadzenie tzw. planu socjalnego - przygotowanie schematu kosztów i finansowania,

- składanie wniosków o środki pomocowe,

- zakup i sprzedaż działek z wolnej ręki,

- zlecenie zadań budowlanych w celu realizacji zamierzeń gminy,

- doradztwo,

- zawarcie umów na prace modernizacyjne i remontowe,

- przeprowadzenie zadań urbanistycznej rewitalizacji, tzn. przeprowadzenie leżących w obowiązku gminy zadań związanych z procesem rewitalizacji, jak uzbrojenie terenu i przygotowanie go pod zabudowę,

- zakup działek lub prawa do ich użytkowania - w imieniu gminy - w celu przygotowania lub przeprowadzenia rewitalizacji,

- zarządzanie środkami służącymi rewitalizacji,

- sterowanie projektem,

- public relations $^{23}$.

Firmy zewnętrzne działające na polu rewitalizacji mogą mieć status operatora-powiernika. Spółka operatorsko-powiernicza jest wówczas nie tylko zarządcą odpowiedzialnym za przeprowadzenie procesu na zlecenie i w interesie gminy, ale posiada również status powiernika, co oznacza, że może tworzyć majątek powierniczy i przejmować do tego majątku nieruchomości będące własnością gminy, a znajdujące się na obszarze rewitalizacji. Takie uprawnienia firmy operatorsko-powierniczej umożliwiają skuteczne przygotowywanie nowych projektów rewitalizacji oraz przeprowadzenie prywatyzacji lub remontów obiektów komunalnych.

Działalność firmy operatorsko-powierniczej obejmuje zróżnicowane zadania i w związku z tym wymaga współpracy ekspertów różnych dziedzin, w tym architektów, urbanistów, inżynierów, geografów, specjalistów z dziedziny gospo-

${ }^{23}$ G. Adamczyk-Arns, Rewitalizacja Starego Miasta w Stralsundzie 1990-2006, [w:] B. Walczak (red.), Rewitalizacja - nośnik tożsamości i rozwoju obszarów metropolitalnych, International Conference Prorevita 2006, Łódź 2007. 
darki mieszkaniowej i ekonomiki przemysłu, prawników, ekonomistów, specjalistów komputerowych, księgowych i fachowców ds. rozliczeń.

Ponadto do zadań firmy operatorsko-powierniczej należy:

- pozyskiwanie środków finansowych z funduszy pomocowych krajowych i zewnętrznych,

- zarządzanie środkami przeznaczonymi na cele rewitalizacji - tworzenie odpowiedniego montażu finansowego, gwarantującego najwyższą skuteczność planowanych działań rewitalizacyjnych - głównie poprzez przeprowadzenie odpowiednich działań publicznych, które zmobilizują inwestorów prywatnych,

- monitoring i ewaluacja procesu rewitalizacji oraz

- rozliczenie wykorzystanych środków wobec instytucji płatniczych.

Powyższe uwagi dotyczące modeli wdrażania rewitalizacji zbieżne są z wynikami analiz przeprowadzonych przez Instytut Rozwoju Miast ${ }^{24}$, w których podsumowaniu stwierdzono, że dla usprawnienia zarządzania procesem rewitalizacji w Polsce należy wprowadzić odpowiednie regulacje legislacyjne wspomagające istniejące instytucje i powołać do życia nowe instytucje. Zaproponowano wpisanie problemu rewitalizacji obszarów zdegradowanych do zestawu zadań własnych gminy - wyraźne określenie, że rewitalizacja miast jest usługą publiczną, miałoby zapewnić nie tylko podjęcie przez gminy odpowiednich działań, ale także umożliwić ich finansowanie. Do finansowego wsparcia rewitalizacji na szczeblu krajowym należałoby utworzyć Krajowy Fundusz Rewitalizacji.

W celu wdrażania programów rewitalizacji zasugerowano konieczność powołania instytucji rewitalizacyjnego powiernika gminy. Gmina pełniłaby funkcje kontrolną, natomiast realizacja przedsięwzięcia rewitalizacyjnego spoczywałaby na wyspecjalizowanym podmiocie zewnętrznym. Obecnie w Polsce nie ma firm specjalizujących się w tego typu zadaniach, a wprowadzenie na rynek nieruchomości nowej specjalistycznej instytucji wymagałoby sprecyzowania jej relacji z gminą i innymi podmiotami zaangażowanymi w proces rewitalizacji. Szczegółowego określenia wymagałaby również procedura sporządzania programu rewitalizacji, zapewniająca klarowność przyjętych zasad i określoną minimalną zawartość programu ${ }^{25}$.

Konkretne propozycje rozwiązań organizacyjnych związanych z zarządzaniem programami rewitalizacji przedstawiono w rozdz. 3.8.

${ }^{24}$ Projekt badawczy-zamawiany pt. Rewitalizacja miast polskich jako sposób zachowania dziedzictwa materialnego i duchowego oraz czynnik zrównoważonego rozwoju, realizowany przez IRM od czerwca 2007 do czerwca $2010 \mathrm{r}$.

${ }^{25} \mathrm{M}$. Bryx, Infrastruktura rynku nieruchomości jako wsparcie procesów rewitalizacji-luka instytucjonalna i re gulacyjna, [w:] M. Bryx (red.), Finansowanie i gospodarka nieruchomościami w procesach rewitalizacji, Rewitalizacja Miast Polskich, t. 7, Kraków 2009. 


\subsection{Public relations i partycypacja spoleczna w procesie rewitalizacji}

Public relations to świadome, celowe i systematyczne zarządzanie procesami komunikacji pomiędzy władzami lokalnymi a wszystkimi podmiotami i osobami czynnie oraz biernie związanymi z realizacją programu rewitalizacji. W praktyce oznacza to metodyczne starania o zrozumienie zakładanych celów rewitalizacji oraz budowę i rozwijanie zaufania lokalnej społeczności wokół realizowanych zadań i projektów.

Celem PR w zarządzaniu programem rewitalizacji jest:

- rozpowszechnianie informacji o programie, budowa świadomości, przekonywanie do dokonanych wyborów strategicznych,

- zdobywanie poparcia, stworzenie i utrzymanie właściwego klimatu sprzyjającego realizacji programu,

- budowa płaszczyzny dialogu pomiędzy władzą lokalną a mieszkańcami, analiza i interpretacja opinii publicznej (partnerstwo publiczno-prywatne),

- doradzanie i informowanie władz lokalnych i wszystkich realizatorów programu o społecznym odbiorze podjętych działań ${ }^{26}$.

Podstawowe znaczenie dla efektywnej realizacji i sukcesu procesu rewitalizacji ma partycypacja społeczna, czyli udział lokalnej społeczności w przygotowaniu programu i jego wdrażaniu. Prowadzenie procesu rewitalizacji powinno od samego początku być ukierunkowane na aktywizację lokalnej społeczności, działalność promocyjną i informacyjną oraz świadczenie pomocy mieszkańcom. Działania te mają na celu poznanie potrzeb mieszkańców i na tej podstawie budowę priorytetów programu rewitalizacji, zwiększenie akceptacji społecznej dla planowanych projektów rewitalizacji oraz podnoszenie gotowości współdziałania poszczególnych uczestników procesu.

Wszelkie aktywności mające na celu włączenie społeczności lokalnej w planowane działania muszą biec równolegle do całego zaprogramowanego procesu. Pierwszym krokiem powinno być poinformowanie mieszkańców o zidentyfikowaniu obszarów kryzysowych, ich zasięgu oraz o zamierzeniach władz lokalnych dotyczących prowadzenia programu ich rewitalizacji. Dalszym etapem jest rozbudowanie współpracy z mieszkańcami, co pozwoli uzyskać informacje o potrzebach i preferencjach $\mathrm{w}$ zakresie działań naprawczych. W momencie opracowania wstępnych koncepcji rewitalizacji, plany przedsta-

${ }^{26}$ Uproszczony Lokalny Program Rewitalizacji wybranych obszarów śródmiejskich oraz pofabrycznych Łodzi na lata 2004-2013 (uchwała nr XXXIV/568/04 Rady Miejskiej w Łodzi z dnia 14 lipca 2004 r., zmieniona uchwałą nr XLIII/753/05 Rady Miejskiej w Łodzi z dnia 19 stycznia 2005 r.). 
wiane są do konsultacji i zbierane są wnioski. Tego typu konsultacje mają często formę warsztatów, w których biorą udział wszystkie zainteresowane procesem rewitalizacji strony. Istotną rolę odgrywają tu eksperci i specjaliści wspierający swą wiedzą władze lokalne w uzyskaniu zamierzonych efektów działań w realizacji celów interesu publicznego. Po wprowadzeniu do programu zmian wnioskowanych przez lokalną społeczność, właścicieli nieruchomości, przedsiębiorców, przedstawicieli instytucji, związków, stowarzyszeń i organizacji, następuje etap wdrażania proponowanych zadań. W tej fazie programu partycypacja społeczna nabiera wymiaru fizycznego i manifestuje się w zaangażowaniu społeczności lokalnej w realizację programu.

Sprawą zasadniczej wagi - szczególnie w warunkach polskich, przy niskim stopniu partycypacji społecznej, wynikającym z uwarunkowań kulturowych, społecznych i historycznych - jest kwestia przekonania mieszkańców, iż ich udział $\mathrm{w}$ programie nie jest tylko działaniem pozornym, ale umożliwia im faktyczny wpływ na planowane działania. Społeczność lokalna często nieufnie podchodzi do propozycji wszelkich zmian. Częstą postawą jest pasywność lub apatia, co często ma miejsce w obszarach bardzo zdegradowanych, o rozległych problemach społecznych.

\section{Środki komunikacji}

W prowadzeniu dialogu ze społecznością lokalną wykorzystuje się różnego rodzaju środki przekazu.

Są to środki pośrednie - medialne, takie jak:

- prasa, radio, telewizja;

- materiały drukowane - broszury informacyjne, foldery;

- reklamy wielkoformatowe - postery;

- ogłoszenia w tradycyjnie przyjętych lokalnie miejscach (kościoły, przystanki komunikacji zbiorowej).

Do środków bezpośrednich - interaktywnych można zaliczyć:

- zebrania mieszkańców, warsztaty, spotkania z ekspertami i reprezentantami władz lokalnych;

- działania informacyjne i konsultacje prowadzone przez operatora rewitalizacji.

W ramach koncepcji promocji Zintegrowanego Programu Rewitalizacji obszarów centralnych Łodzi ProRevita zaproponowano znacznie szerszy zakres kanałów komunikacji:

- radio, TV, prasa,

- prasa osiedlowa,

- kancelarie notarialne, 
- biura nieruchomości, deweloperzy, zarządcy, administracje domów i budynków,

- domy opieki społecznej, kuratorzy, placówki wychowawcze, organizacje charytatywne, organizacje kościelne,

- miejskie punkty informacyjne o programie rewitalizacji, uruchomione w dzielnicowych delegaturach urzędu miasta,

- ogłoszenia w miejscach publicznych,

- ogłoszenia w środkach komunikacji publicznej,

- ulotki w miejscach często odwiedzanych przez łodzian, np. Galeria Łódzka, Central, Urząd Miasta Łodzi przy ul. Piotrkowskiej, Teatr Wielki, hipermarkety, banki, taksówki,

- ulotki rozpowszechniane w trakcie imprez masowych, np. w trakcie dni święta Łodzi,

- uchwały rady miejskiej, dziennik Urzędu Miasta Łodzi,

- partie polityczne, biura poselskie,

- organizacje pozarządowe ${ }^{27}$.

Obecnie coraz większą rolę jako narzędzie partycypacji społecznej zyskuje Internet $\mathrm{i}$ poczta elektroniczna. Wiele gmin $\mathrm{w}$ Polsce na swoich stronach internetowych, w ramach Biuletynu Informacji Publicznej (BIP) umieszcza informacje związane $\mathrm{z}$ prowadzonymi programami rewitalizacji. Platforma internetowa umożliwia również prowadzenie konsultacji społecznych poprzez korespondencję elektroniczną. Tego typu korespondencja związana z tematyką rewitalizacji powinna być ogólnie dostępna $\mathrm{w}$ ramach internetowego forum dyskusyjnego ${ }^{28}$. Nadal istotną barierą w Polsce prowadzenia akcji informacyjnej i promocyjnej oraz konsultacji w systemie elektronicznym jest ograniczony dostęp społeczeństwa do Internetu i znajomość posługiwania się komputerem (tzw. wykluczenie cyfrowe), szczególnie w przypadku osób starszych.

Dużą rolę w skuteczności komunikacji z uczestnikami procesu rewitalizacji odgrywa forma zapisu graficznego rysunków, schematów i planów. Jest sprawą zasadniczej wagi, aby były one wykonane w sposób przejrzysty i przy użyciu oznaczeń graficznych umożliwiających zrozumienie przedstawianych zagadnień osobom nieprzygotowanym profesjonalnie do interpretacji graficznych zapisów planistycznych. Często dla ułatwienia odbioru treści planów przedstawia się obszar rewitalizacji w postaci aksonometrii lub konstruuje się jego makietę. Stosowanie tego rodzaju środków zapisu proponowanych przekształceń przestrzennych ma podstawowe znaczenie dla możliwości nawiązania faktycznego i konstruktywnego dialogu pomiędzy lokalną społecznością a specjalistami przygotowującymi program rewitalizacji i pracującymi nad jego realizacją.

\footnotetext{
${ }^{27}$ P. Szymański, Konsultacje społeczne, [w]: Zintegrowany Program Rewitalizacji...

${ }^{28}$ Podręcznik rewitalizacji...
} 
Rozwiązania organizacyjne umożliwiające realizację działań promocyjnych rewitalizacji oraz partycypację społeczną zaprezentowane zostały w rozdz. 3.9.

\subsection{Partnerstwo publiczno-prywatne (PPP) w procesie rewitalizacji}

Określenie partnerstwo publiczno-prywatne (PPP) odnosi się do różnego rodzaju form współpracy pomiędzy władzami publicznymi a sektorem prywatnym dla zapewnienia finansowania, tworzenia, modernizacji, zarządzania i utrzymania infrastruktury lub wykonania usług.

Partnerstwo publiczno-prywatne definiowane jest jako ,instrument używany do realizacji wszelkiego rodzaju usług publicznych. Terminem partnerstwa publiczno-prywatnego określa się projekty inwestycyjno-eksploatacyjne realizowane $\mathrm{w}$ oparciu o umowę długoterminową wspólnie przez władze publiczne i podmioty sektora prywatnego (podmioty rynkowe), których celem jest stworzenie niezbędnej infrastruktury rzeczowej, finansowej i organizacyjnej, umożliwiającej świadczenie usług publicznych"29.

Podkreśla się, że PPP jest tworzone w celu osiągnięcia najbardziej efektywnej realizacji celów, do jakich obie strony tej współpracy zostały powołane: partner publiczny - świadczenia usług publicznych, a partner prywatny - prowadzenia działalności gospodarczej ukierunkowanej na osiaganie zysków. Ideą PPP jest oddzielenie domeny działalności politycznej od gospodarczej - sprywatyzowane zostają działania gospodarcze, natomiast władza publiczna nadal ponosi odpowiedzialność za jakość i poziom dostępności świadczonych społeczeństwu usług publicznych.

Partner publiczny określa cele, jakie mają być osiagnięte $\mathrm{w}$ interesie publicznym, jakość dostarczanych usług oraz politykę cenową, a także bierze odpowiedzialność za monitorowanie tych celów. Współpraca pomiędzy partnerem publicznym i prywatnym obejmuje różne aspekty planowanego projektu. Charakterystyczną cechą PPP jest także model finansowania, polegający na łączeniu funduszy publicznych i prywatnych dla realizacji założonego przedsięwzięcia. Udział stron w ponoszeniu ryzyka jest zależny od indywidualnych cech danego projektu.

Realizacja zadań publicznych w systemie PPP przynosi pozytywne efekty szczególnie w przypadku:

- potrzeby radykalnego zwiększenia inwestycji w sferze usług publicznych,

- braku środków publicznych, które mogą na ten cel być wydatkowane,

- niskiej efektywności, wysokich kosztów oraz niesprawnego zarządzania w realizowaniu zadań przez władze publiczne.

${ }^{29}$ I. Herbst, Warunki finansowania procesów rewitalizacji w gospodarce rynkowej, [w:] M. Bryx (red.), Finansowanie i gospodarka... s. 134. 
PPP stosowane jest w dziedzinach, w których realizacja zadań wyłącznie przez sektor publiczny nie jest uzasadniona i korzystna - ze względów finansowych, organizacyjnych, a także merytorycznych (np. know-how oraz metody pracy stosowane przez sektor prywatny). Do takiego modelu współdziałania kraje członkowskie Unii Europejskiej sięgają często w przypadku realizacji projektów infrastrukturalnych, szczególnie w dziedzinie transportu, ochrony zdrowia, edukacji oraz bezpieczeństwa.

Efektywność realizacji zadania na bazie modelu PPP powinna być oceniana dla każdego przedsięwzięcia indywidualnie ${ }^{30}$.

${ }^{30}$ Green paper on public-private partnerships and community law on public contracts and concessions, COM(2004) 327 final. 